\title{
O Novo Diretor da Faculdade de Direito: Professor Doutor Dalmo de Abreu Dallari
}

No dia 14 de julho de 1986 foi empossado o novo Diretor da Faculdade de Direito, Professor Doutor DALMO DE ABREU DALLARI.

Nascido em Serra Negra, no Estado de São Paulo, em 31 de dezembro de 1931, filho de Bruno Aguinaldo Dallari e de D. Áurea de Abreu Dallari, foi aluno, naquela cidade, do Externato Sagrada Familia e do Grupo Escolar Lourenço Franco de Oliveira, onde concluiu o curso primário. No ano de 1947 a familia transferiu-se para São Paulo, com o objetivo de proporcionar aos filhos a possibilidade de prosseguirem nos estudos.

Tendo-se mudado para São Paulo em 1947, o Professor Dalmo de Abreu Dallari foi aluno do Colégio Estadual Presidente Roosevelt, onde concluiu o curso clássico em 1952. No início do ano seguinte ingressou na Faculdade de Direito do Largo de São Francisco, mediante aprovação nos exames vestibulares, tendo concluído o curso de bacharel em ciências jurídicas $e$ sociais no ano de 1957.

Durante o período em que foi aluno do curso de bacharelado sua atividade acadêmica foi muito intensa, tendo sido presidente da Academia de Letras da Faculdade e redator-chefe do jornal e da revista XI de Agosto, sendo premiado pelo Ministério de Educaçâo e Cultura pela publicação do melhor órgâo de imprensa estudantil do Brasil. Teve também ativa militância política, chegando a ocupar a presidência do Partido Acadêmico Libertador, pelo qual concorreu à presidência do Centro Acadêmico XI de Agosto no ano de 1956.

Ainda como estudante foi selecionado para integrar a representação naulista no $V$ Congresso Jurídico Estudantil Brasileiro, realizado em Belo Horizonte no ano de 1955. Foram seus companheiros, nessa oportunidade, os acadêmicos José Afonso da Silva, que hoje é também Professor Titular da Faculdade de Direito da USP, Luiz Vicente Cernichiaro, agora Professor da Universidade de Brasília, Mário Chamie, poeta e jornalista que foi Secretário 
da Cultura no Município de São Paulo, Donaldo Armelin, atualmente Procurador do Estado de São Paulo e Ronald Caputo, tributarista e empresário, radicado em Santa Catarina.

Após a conclusão do curso de bacharelado o Professor Dalmo de Abreu Dallari realizou vários cursos de Especialização na Faculdade de Direito da USP, os quais eram dados em nível de pós-graduação, antes da criação dos cursos de Mestrado e Doutorado no Brasil. Fez também um curso de Língua e Civilização Francesas, no Instituto Católico de Paris.

Desde o curso de Especializaçāo iniciou colaboração informal, visando o ingresso na carreira docente, com o Professor José Carlos de Ataliba Nogueira, sob cuja influência decidiu especializar-se em Teoria Geral do Estado. No ano de 1963 prestou concurso para a Livre Docência dessa disciplina, na própria Faculdade de Direito da USP, obtendo aprovação e passando a integrar o quadro de docentes da Faculdade a partir de março de 1964. Desenvolveu, então, intensa colaboração com o Professor Ataliba Nogueira, que o tomou como assistente e lhe deu a incumbência de reger a disciplina no curso noturno.

Poucos meses depois, tendo o Professor Ataliba Nogueira assumido o cargo de Secretário da Educação do Estado de São Paulo, o Professor Dalmo de Abreu Dallari ficou encarregado da regência do curso de tipos de Estudos Modernos, em nível de Mestrado. Inicia-se aí uma fase de intensas atividades universitárias, ao mesmo tempo em que sāo dados os primeiros passos para a resistência às ofensas aos direitos fundamentais dos brasileiros, decorrentes da deposição do presidente constitucional João Goulart e restauração de um governo militar.

Desde então o Professor Dalmo de Abreu Dallari passou a ocupar posição destacada na denúncia de violaçāo de direitos e na exigência de restauração da normalidade democrática. Por meio de conferências, proferidas em muitos pontos do Brasil, sobretudo a convite de organizaçöes estudantis, comunitárias e profissionais, bem como através de entrevistas freqüentes e da publicação de artigos no jornal "Folha de S. Paulo", sua presença foi marcante, na exigência de respeito à dignidade e aos direitos dos perseguidos políticos. Suas denúncias tiveram grande repercussāo no Brasil e no exterior, sobretudo a partir de 1972, quando ajudou a organizar a Comissão Pontifícia Justiça e Paz, da Arquidiocese de São Paulo, da qual foi o primeiro Presidente, colaborando estreitamente com o Cardeal-Arcebispo de São Paulo, D. Paulo Evaristo Arns, um dos mais corujosos e eficientes defensores dos Direitos Humanos nesse período.

Em função de suas atividades universitárias e de sua participação em grupos e entidades defensoras de pessoas e segmentos sociais marginalizados, 


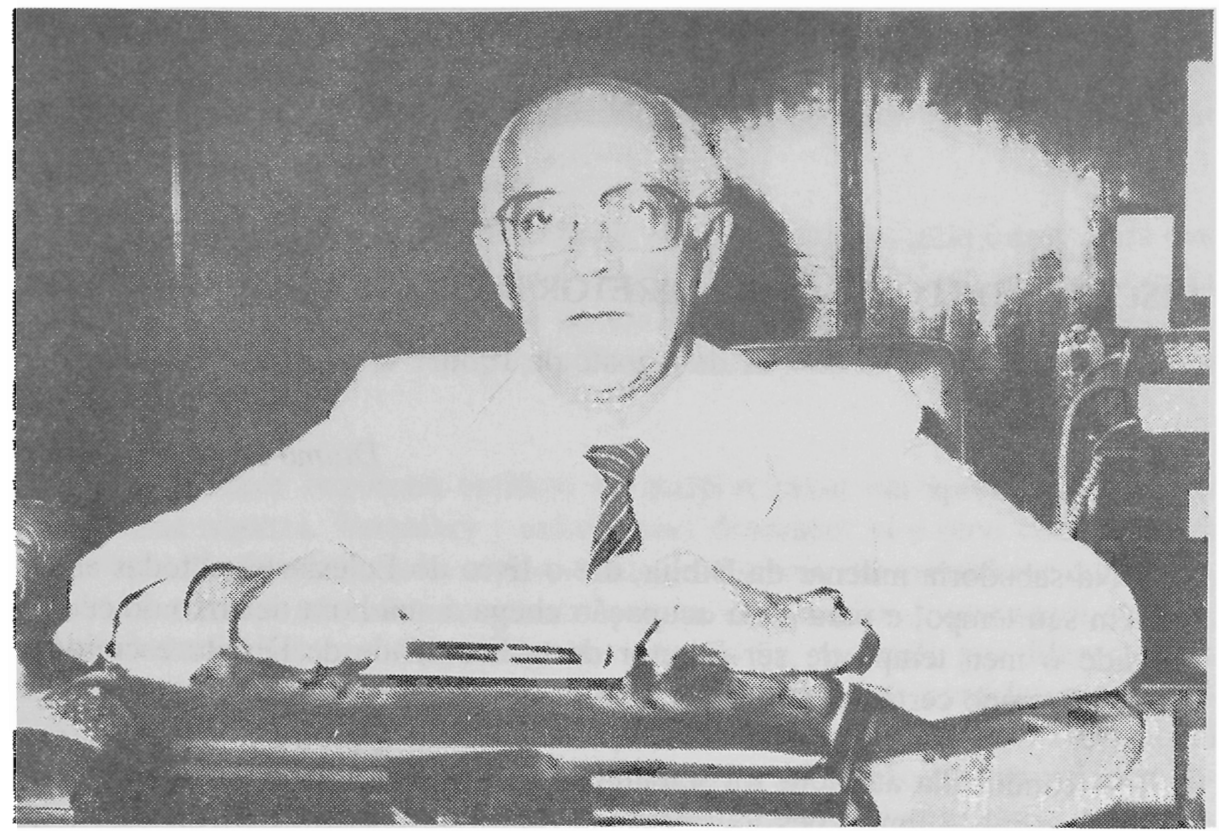

escreveu inúmeros trabalhos e participou de muitos cursos, congressos e seminários no Brasil e no exterior, retirando diretamente de sua prática os elementos para uma produção teórica realista e atualizada.

No ano de 1974 foi o vencedor de concurso público para Professor Titular de Teoria Geral do Estado, apresentando tese denominada " $O$ Futuro do Estado". Prosseguindo em suas atividades universitárias o Professor Dalmo de Abreu Dallari vem ministrando cursos em nível de graduação e pós-graduação, além de promover cursos extracurriculares e de colaborar com instituiçōes de apoio à pesquisa. Por tudo isso e por ter estado sempre d̀. frente de movimentos de defesa da democracia e dos Direitos Humanos foi o nome que recebeu maior votação dos professores, estudantes e funcionários da Faculdade de Direito em consulta informal para escolha do novo Diretor da Faculdade. Depois disso foi incluido em lista tríplice organizada pela Congregação da Faculdade e, finalmente, escolhido pelo Magnífico Reitor José Goldemberg para Diretor da velha Academia do Largo de São Francisco.

O Professor Dalmo de Abreu Dallari foi casado em primeira núpcias com a Drي Martha Bohomoletz de Abreu Dallari, já falecida, tendo desse casamento os filhos, Pedro, Martha Maria, Bruno, Maria Paula, Mônica e Renata. É casado atualmente com a Dr ${ }^{a}$ Sueli Gandolfi Dallari, acrescentando-se aos seus filhos, por esse casamento, mais uma filha, Maria Beatriz. Tem um neto, Paulo, filho do Dr. Pedro Dallari. 